\title{
Ocorrência de maus-tratos em crianças: formação e possibilidade de ação dos fonoaudiólogos
}

\author{
Occurrence of child abuse: knowledge and possibility of \\ action of speech-language pathologists
}

Milica Satake Noguchi* (milica.noguchi@uol.com.br)

Simone Gonçalves de Assis **

Juaci Vitória Malaquias***

*Fonoaudióloga. Doutora em Ciências - Escola Nacional de Saúde Pública (ENSP)- Fundação Oswaldo Cruz (FIOCRUZ) (RJ). Endereço para correspondência:

Rua João Moura 870 - Apto. 62 São Paulo - SP - CEP 05412-002 (milica.noguchi@uol.com.br).

**Médica. Doutora em Ciências - ENSP / FIOCRUZ (RJ). Pesquisadora Titular do Centro Latino Americano de Estudo de Violência e Saúde Jorge Coreli (CLAVES)/ENSP/FIOCRUZ

***Estatístico. Mestrando em Estudos Populacionais e Pesquisas Sociais Escola Nacional de Ciências Estatísticas (ENCE) - Instituto Brasileiro de Geografia e Estatística (IBGE). Pesquisador do CLAVES/ ENSP/FIOCRUZ.

*****Trabalho realizado no CLAVES/ ENSP/FIOCRUZ (RJ)

Artigo de Pesquisa

Artigo Submetido a Avaliação por Pares

Conflito de Interesse: não

Recebido em 15.09.2004. Revisado em 14.12.2004; 07.07.2005; 14.10.2005; 03.01.2006; 21.02.2006. Aceito para Publicação em 21.02.2006.

\begin{abstract}
Background: this work presents the results of an epidemiological survey about the professional experience of Speech-Language Pathologists and Audiologists of Rio de Janeiro (Brazil) with children and adolescents who are victims of domestic violence. Aim: to understand the occurrence of child abuse and neglect of children and adolescents treated by speech-language pathologists, characterizing the victims according to: most affected age group, gender, form of violence, aggressor, most frequent speech-language complaint, how the abuse was identified and follow-up. Method: 500 self-administered mail surveys were sent to a random sample of professional living in Rio de Janeiro. The survey forms were identified only by numbers to assure anonymity. Results: 224 completed surveys were mailed back. 54 respondents indicated exposure to at least one incident of abuse. The majority of victims were children, the main abuser was the mother, and physical violence was the most frequent form of abuse. The main speech disorder was late language development. In most cases, the victim himself told the therapist about the abuse - through verbal expression or other means of expression such as drawings, story telling, dramatizing or playing. As the majority of the victims abandoned speech-language therapy, it was not possible to follow-up the cases. Conclusion: due to the importance if this issue and the limited Brazilian literature about Speech-Language and Hearing Sciences and child abuse, it is paramount to invest in the training of speech-language pathologists. It is the duty of speech-language pathologists to expose this complex problem and to give voice to children who are victims of violence, understanding that behind a speechlanguage complaint there might be a cry for help.
\end{abstract}

Key Words: Child Abuse; Speech, Language and Hearing Sciences; Speech-Language Pathology, Negligence.

\section{Resumo}

Tema: este trabalho apresenta os resultados de um inquérito epidemiológico realizado com fonoaudiólogos da cidade do Rio de Janeiro (Brasil) acerca de sua experiência profissional com crianças e adolescentes vítimas de violência familiar. Objetivo: conhecer a ocorrência dos maus-tratos na clientela atendida por esses profissionais, caracterizando as vítimas quanto a faixa etária mais atingida, sexo, tipo de violência sofrida, agressor e tipo de queixa fonoaudiológica mais freqüente, além de conhecer como a violência foi identificada e qual foi a evolução dos casos. Método: foram enviados 500 questionários auto-administráveis por correio para uma amostra aleatória de fonoaudiólogos do Rio de Janeiro. Os questionários retornados foram identificados somente por números para garantir o anonimato. Resultados: dos 224 fonoaudiólogos que responderam ao questionário, 54 atenderam pelo menos um caso de mautrato, sendo a maioria composta por crianças. O principal agressor foi a mãe e o tipo de violência mais identificada foi a física. $\mathrm{O}$ atraso de linguagem foi a queixa fonoaudiológica mais frequiente nas vítimas de violência e a principal forma de identificação foi o relato da própria vítima ao profissional - relato verbal ou ainda, por meio de desenhos, estórias contadas, dramatizações e brincadeiras. Quanto a evolução, a maioria abandonou o tratamento fonoaudiológico impossibilitando o acompanhamento dos casos. Conclusão: dada a importância do tema para a área e a escassez de trabalhos existentes no Brasil sobre Fonoaudiologia e maus-tratos infantis, é imprescindível investir no trabalho de formação e informação deste profissional. É tarefa ainda do fonoaudiólogo, dar visibilidade a um problema tão complexo e principalmente, "dar voz" às crianças vítimas de violência, compreendendo que por trás de uma queixa fonoaudiológica pode haver um pedido de socorro.

Palavras-chave: Maus-Tratos Infantis; Fonoaudiologia; Negligência; Patologia da Fala e da Linguagem. 


\section{Introduction}

This study approaches the interpersonal violence towards children and adolescents with the family as the main locus. The terms "child abuse and neglect" and "child maltreatment" practiced by parents or care-takers are adopted to designate the phenomenon studied in this research.

There is a broad literature approaching the importance of the doctor, the dentist, the nurse, the social worker and the psychologist concerning the identification, prevention and follow up of child abuse cases, and the necessity to graduate and capacitate those professionals to face this serious problem (Braz \& Cardoso, 2000; Lima \& Gamonal, 2000; Gomes, et al., 2002; Gonçalves \& Ferreira, 2002). However, no previous study was found in the main literature data base (in English and in Portuguese) regarding the speechlanguage pathologist (Medline, Lilacs, Pubmed, ISIweb of Knowledge, Scielo, PsycINFO/APA). There is also a lack of studies relating communication disorders and maltreatment in the international and in the Brazilian publications; this subject is still little explored in the area's scientific productions.

In an attempt to insert this theme in the Speech, Language and Hearing Sciences debates, this pioneer study was developed in Brazil with a sample of speech-language pathologists of Rio de Janeiro city, searching to know these professionals' experience with children and adolescents victims of abuse and neglect. The first part of this study's results discussed the speech-language pathologists difficulties facing the abuse and neglect problem, from the analysis of the their working place, their management and the closure of the abuse cases. These results were published in an article entitled "Within four walls: speechlanguage treatment for abused children and adolescents" (Noguchi et al., 2004).

The second part of the results, that will be presented in this article, searched for characterizing the neglect victim, the perpetrator, the speech-language complaint presented by those children and adolescents, besides understanding how the speech and hearing therapists identified and followed up these cases.

\section{Method}

This study was approved by the Research Ethics Committee of the National Public Health
School /FIOCUZ under the protocol no 126/03.

An epidemiological survey was performed using self-administered questionnaires mailed together with an explanatory letter assuring the anonymity and a stamped return envelope.

The sampling was outlined using a list provided by the Regional Speech, Language and Hearing Council - 1st. region (Rio de Janeiro), computing all the 3.113 speech and hearing pathologists of the mentioned city. The sample was defined admitting an estimation error of $4 \%$ and an associated risk of $5 \%$, totalizing a sample size of 500 individuals (Cochran, 1965). Four months after the first mail, a total of 224 answered questionnaires were received, indicating a loss of $55,2 \%$.

Aiming at reaching the main purpose of this study and, at the same time, respecting the ethical and juridical issues involved, the absolute anonymity of the respondents was assured, and the researcher who identified the received questionnaires used only numbers.

The variables of the questionnaire that will be studied in this article are: most frequent type of speech and hearing disorder of the interviewed therapists' clients, treating experience of abused babies, children and adolescents; number of cases treated along their professional lives, the age group and gender of the victims, type of maltreatment suffered, identification of the perpetrator and most common type of the victims' speech-language disorder. The open questions refer to how the abuse was identified and to the improvement of the speech-language disorder.

In order to process the information of the questionnaires, a data base was created in the program Epi-info, version 6.0. This data base was converted into the software SPSS, version 8.0, in the analysis phase, and the simple frequency, the bi-variate analysis and the statistical test to verify the significance (Person Chi-square test) were performed. Only the crossings with a significance level inferior than $5 \%(\mathrm{p}<0,05)$ were reported in the text and the statistical test was considered acceptable. The small sample of professionals who actually treated some case of abuse and neglect made the statistically significant associations difficult.

The qualitative variables of the questionnaire, such as the open questions were categorized in order to enable a descriptive analysis to complement the discussion of the results. 


\section{Results}

Of the 224 speech-language pathologists who answered the questionnaire, $54(24,1 \%)$ treated at least one case of abused baby, child or adolescent. Most of the interviewed reported they have never treated those cases $(75,9 \%)$.

Within the 54 speech-language pathologists who had experience with abused patients, it was observed that the most affected age group was children from 2 to 11 years old (at least 50 cases), followed by adolescents (at least 21 cases) and by babies (at least 14 cases). This result is not exact, once the professional was only inquired if he had already treated in his professional life one, two, three or more cases of patients with neglect history.

The average of abused patients treated by the speech-language pathologists was: 1,6 babies per professional; 2,9 children and 2,1 adolescents.

Concerning the abused cases treated in the last year, it was verified that 6 professionals treated babies, 36 treated children, and 12 treated adolescents. During the whole professional life, 14 professionals treated abused babies, 50 treated children and 21 treated adolescents, indicating that $42,8 \%$ of the babies treatments, $72 \%$ of the children treatments and $57,1 \%$ of the adolescents treatments correspond to the last year. This can indicate that the child maltreatment identification by the speechlanguage pathologist is a recent phenomenon.

Regarding the victims' gender, it was observed only among the children, a slight increase of male victims $(2,6$ treatments by professional) compared to female victims $(2,1)$. In general, 8 professionals treated babies of both genders; 33 treated girls from 2 to 11 years old; and 36 treated boys of the same age. Thirteen professionals treated female adolescents and 15 treated male adolescents.

As regards to the most frequent type of maltreatment suffered by children and adolescents treated by the 54 speech-language pathologists, it was observed that the most common type was the physical abuse (77\%), followed by the psychological abuse (72\%), neglect/ abandon $(67 \%)$ and, at last, by sexual abuse (59\%).

The main perpetrator identified by the speechlanguage pathologists was the mother $(70 \%)$, followed by the father $(59 \%)$, both mother and father $(41 \%)$, stepfather or stepmother $(40 \%)$, brother or sister $(31 \%)$, neighbor or friend non members of the family (31\%) and other members of the family $(28 \%)$. These results show that it was common the identification of several perpetrators in the same case of abuse.

A significant statistical difference was found between neglect/ abandon and both mother and father as the perpetrators: professionals informed that both mother and father together practice more neglect/ abandon (55\%) than other types of maltreatment $(13,3 \% ; \mathrm{p}<0,05)$.

The type of speech-language disorder reported by the 54 speech-language pathologists who treated children/ adolescents victims of abuse and neglect coincided, in general, with the ordinary patients' disorders treated by the total 224 speech-language pathologists interviewed, as seen in Graph 1.

The language development delay was the most common problem found either between professionals who treated victims, as between those who did not treat such cases. However, the percentage is higher among the victims of maltreatment. In this group there were also problems of reading and writing, genetic syndromes and neurological problems, fluency disorders, voice disorders and problems in the stomatognathic system, hearing loss and audiological evaluation.

Only four types of speech-language disorders differed between the professionals who treated victims and those who did not: language development delay, reading and writing problems, genetic syndromes/ neurological problems and fluency problems.

Despite not being a type of speech-language disorder, the audiological evaluation was included in the graph because it is also practiced by this professional, although with different characteristics from the speech-language therapy.

Within the speech-language pathologists who had some experience with maltreatments, it was found a significant difference between neglect/ abandon and genetic syndromes/ neurological problems: $80 \%$ of the professionals who informed having treated victims with this type of disorder identified neglect/ abandon as the most frequent type of maltreatment.

According to the 54 interviewed pathologists, the victims' report was the main factor contributing for the maltreatment identification (21 occurrences). This report was not only verbally, but many times through drawings, story telling, dramatizations and playing.

The child's behavior observation was the second most reported factor, with 18 occurrences. 
The child's behavior was described by the respondents in different ways, being the most frequent ones "aggressiveness" (4 occurrences) and "changing of behavior when facing the perpetrator" (3). Other reported characteristics were: hyperactivity, low self-esteem, excessive anxiety, irritability, isolation, affection privation and fear.

The body marks were the third most mentioned factor in the maltreatment identification (13 occurrences). Those marks were characterized by burns provoked by cigarettes or iron, or even bruises on the child/ adolescent's body.

The communication with the family, that was also a very cited factor by the interviewed pathologists (16 occurrences), gathered the spontaneous report of a care-taker or a situation where the speech pathologists searched for this information, asking direct or indirectly. The term "family report" may represent the mother alone, the parents, or other relative contacted by the speech pathologist and who talked about the episode.

Some speech-language pathologists did not need to observe the occurrence of maltreatment in his patients, once the care-taker himself or the accompanying person reported the episodes of abuse or neglect. They were usually cases of adoption (4 cases), situation where another relative takes care of the child 93 cases), or when the Tutelary Council, orphanage or other organ referred the child to the professional.

Concerning the improvement of the speechlanguage disorder presented by the abused child/ adolescent, it was observed that the lack of follow up and abandon of the treatment were mentioned by 30 respondents. There were 15 reports of good improvement in cases where there was some kind of intervention with the parents and/ or the children (specially psychological); in 9 cases there was no improvement of the disorder and no intervention; and in 2 cases there was improvement and the parents were counseled and followed by the speech pathologist.

GRAPH 1. Distribution of the most frequent type of speech-language disorder between children and adolescents treated by speech-language pathologists.

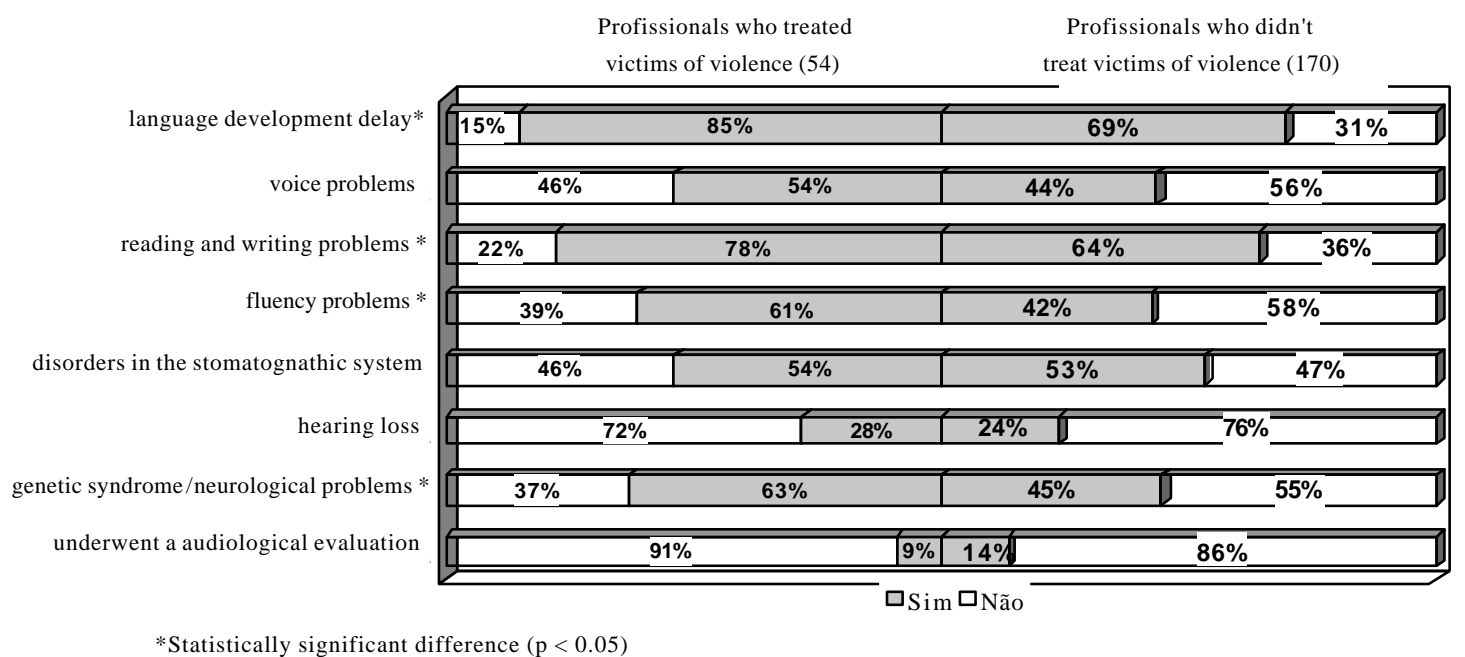




\section{Discussion}

Regarding the most affected age group, the findings of this study corroborate the data from the Assistance for Prevention of Accidents and Violence (APAV) of Rio de Janeiro State Health Secretary (SES-RJ, 2004) that found the age group from 1 to 9 years old as the most affected one. Several other national and international studies indicate that small children are more affected by this kind of violence (Deslandes, 1994; Silva, 2001; Mello, 2002).

Concerning the gender of the victim, most of the studies don't point to a clear predominance of one of the genders. Commonly, it's only possible to observe this difference when the gender is associated to the type of maltreatment, as observed in Mello's (2002) study. The data from APAV/SESRJ (2004) and the international statistics, such as Annual Child Maltreatment 2003 based on the American database of maltreatment recordings National Child Abuse and Neglect Data System (NCANDS, 2005), the girls tended to suffer more abuse than boys, contrarily to the results found in this study that pointed a slight increase of boys. This difference may be explained by the fact that language problems in small children are more frequent in boys (Law \& Conway, 1992).

Concerning the type of maltreatment, the speech-language pathologists privileged the physical abuse, more visible and easily identified, than the neglect or even other forms, such as sexual abuse that may occur without leaving an evident physical sign. On the other hand, the fact that the population of this study is or was being treated by a speech-language pathologist indicate that these families give a certain type of care to the children, eliminating more severe forms of neglect, where health is not assisted.

Thus, considering the specificities of our data source, the results found differ from those found in the NCANDS (2005) and in the APAV/SES-RJ (2004) where the neglect was the most frequent type of abuse identified, $60 \%$ and $41 \%$ of the cases, respectively.

It is important to stress that literature indicates the sexual abuse as the most frequent type of abuse in handicapped populations (Sullivan et al.,1991; Kvam,2004).

It is also important to remind the difficulty of the professional to recognize a situation of neglect, once it may be confused with socio-economic difficulties. Deslandes (1994) stresses the difficulty of a more precise analysis of neglect cases, because this type of violence is, many times, in a border situation between poverty and maltreatment, that is, between the impossibility of giving attention and the abusive practice. The report of this speech pathologist illustrates this matter: "small kids who took care of even smaller ones to allow the mother to work were absent students and, therefore, they repeated many times the first grade. When I got there, in 1969, I got a classroom where the students repeated 11 times the same grade" (21).

The typical neglect situations are easily known: "the child arrived dirty, hungry, smelling badly, without shirt, totally neglect" (132); "the mother's refusal to take care, the exaggerated rejection and, evidently, the baby's fall of the bed (21)".

Another very frequent neglect situation, but not very recognized yet as a source of maltreatment by these professionals, is the one characterized by the lack of adhesion of the care-takers to the speech-language treatment of their children: "the child needs treatment (speech-language), but the parents report they can't afford and even when the pathologists affirms that the treatment is free, the parents also don't take their sons showing lack of interest. (...) In another case, the mother abandon (the therapies) because the child would have to do several exams. When the exams were ready, the child even left school. We don't know what the child has. We only know that he/she is without school and without any treatment These cases show very well the lack of interest of their parents. They would rather leave their children without treatment" (155).

This type of neglect frequently faced by the speech-language pathologist in his daily professional life must be carefully evaluated, once it can cover different situations that go from not accepting the child's difficulties until totally neglecting the child's health needs.

Concerning the perpetrator, there is a common sense in the literature and official statistics that point the mother as the main aggressor. The understanding of this finding must take into account the fact that the mother is the person who spends most of the time with the children, and if the father spent the same time with the children, he could be the most frequent perpetrator (Deslandes, 1994).

The result of this research corroborated the findings of international studies concerning the most frequent type of speech-language disorder in maltreated children. In Hammond's et al. (1989) 
study, a language evaluation was performed with 27 abused or neglected children and $22(81 \%)$ presented language development delay. Eigsti \& Cicchetti (2004) studying the dyad mother/son with and without a violent dynamics also found a delay in the syntactic development of abused children who presented a less complex language and a poorer vocabulary compared to children who did not experience maltreatment.

These results, however, differ from those found in the general population, as showed in Andrade's (1997) study about the prevalence rates of speech and language idiopathic disorders in a Health Unit of São Paulo city. In that study, the articulation disorders were the most prevalent ones followed by oral language disorders. The discrepancy of these results compared to the present study may be attributed to the fact that in families where there is a violent dynamics, the interaction adult-child is very problematic and it is essential for the language development.

The patients with genetic syndromes/ neurological disorders and hearing loss were stressed by some pathologists: "abuse strikes surprisingly handicapped people, specially mentally handicapped" (59); "those families go to the deafness ambulatory and I think that if there is a greater intromission, the mother withdraws the child and we don't hear from them anymore" (82); "I get scared with the parents attitudes towards their handicapped children; from my point of view, they should be treated with much more love, attention and dedication" (132).

The international literature has also focused this group of children (handicapped), once they are particularly vulnerable to suffering abuse and neglect, due to their communication problems that make even more difficult the report and to the parental or care-takers stress, increasing their risk of suffering abuse (Sullivan et al., 1991; Deslandes, 1994).

As regards to how the maltreatment was identified, it is worth making some comments about the speech-language treatment peculiarities, already pointed by Noguchi \& Assis (2003).

The victim's report was the most cited factor by the pathologists and generally occurs when the child or adolescent are not together with their care-takers, which are usually the perpetrators.

A long time alone with the child, without the parents, is one of the speech-language treatment characteristics, specially speech-language therapies, reaffirming the importance of this professional in the identification of maltreatments
(Noguchi \& Assis, 2003).

The child or adolescent observation was the second most reported factor by the pathologists, probably because the speech therapy provides a frequent, regular and long contact with the child and his/her family. Besides, the child behavior interferes directly in the speech-language treatment, being difficult for this professional to ignore this aspect.

The body marks were the third most cited factor (13 occurrences). Some interviewed described those marks: "the boy had bruises on the arms because of pinches (...) every time he made a mistake in his home tasks, he got a pinch and stayed without eating" (147). Another interviewed pathologist described that "the child presented a burn on the leg (...) I asked the mother what happened and she told me she was very nervous and touched the child with the hot iron" (178).

In some cases, where the marks were not visible, but the child behavior indicated some problem, the speech pathologist used other means to observe the presence of these marks - "the child arrived in the clinic hyperactive, lost and I realized something had happened. I did some activities that allowed taking the shirt of and I saw violence marks in his/ her skin. (...) I found out the mother had hit the child with a belt" (103).

Many times, the therapy aims at handling and observing structures of the head, specially phonoarticulatory organs, and the neck, thorax and abdomen regions - specially in voice therapy. According to Vieira et al. (1998), 50,2\% of the existing lesions in abused children are located in the head, face and neck region, and this index could be even greater once the intra-oral lesions are not identified.

Thus, the body marks are a very important aspect to be observed by the speech-language pathologist mainly because this professional works with a physical proximity and gives an individualized attention to his patient.

The communication with the family, which was also very cited by the interviewed (16 occurrences) indicates the importance to call other members of the family, such as brothers/ sisters, grandparents, aunts/ uncles, to provide more information about possible cases of abuse or neglect. The close relationship with the patients' family characterized by a frequent contact not only during the interview, anamnesis or evaluation, but during the whole speech-language intervention enables the reports about abuse by the relatives.

This study limited to describe the main identification forms of maltreatments by the speech- 
language pathologist without analyzing the follow up of the case. The difficulties found by health professionals, in general, facing child's abuse have been analyzed by several authors (Deslandes, 1999, Silva, 2001). The practice of the speech-language science focused in a corrective-normalizing perspective (Moreira \& Friedman, 2002; Tfouni et al., 2002) and the coverage of a small group of the society, usually developed in private clinics (Silva \& Massi, 1999), exacerbate these difficulties. A more profound discussions about the historical aspects of this profession in Brazil, interfering with the speech-language pathologist management of maltreatment cases and the reports difficulties can be found in Noguchi et al. (2004).

Concerning the improvement of the speechlanguage disorder of the abused children treated by the speech pathologists, the results point to a worrying fact: since a great part of the cases abandoned the speech-language treatment, it is possible to suppose that they are still suffering maltreatment.

These results also suggest that the improvement of the disorder may be related to the abuse episodes, since all cases that improved were having some kind of intervention. The inverse situation also reaffirms this relation: cases with no improvement in the speech-language disorder didn't have any kind of intervention with the victim and/or with the family. The report of this speech pathologist characterizes precisely this observation "when the patients starts to show improvement, the abuse happens again and he/ she presents a regression" (122).

It was also observed four reports of cases referred to the Tutelary Council (CT- a brazilian child protective service) with negative results for the children, once they remained in a risky situation. A greater discussion about the difficulties faced by the CT and the complex relation between the CT and the health professionals may be found in Silva (2001).

\section{Conclusion}

This study tried to characterize the rate of child abuse and neglect treated by speech-language pathologists, thus contributing for the dissemination of information about this theme and placing it in the Speech-Language and Hearing Sciences debates.

Considering the language development delay as the most frequent type of speech-language disorder found in abused children, it is possible to state that the abuse silences its victims. This silencing is beyond the difficulties expressed in the speech, since many times it crystallizes in the children's cultural values, avoiding them to elaborate thoughts and criticisms about people they love and that molest them, covering up and facilitating the ongoing violence.

Facing this problem is essential for this professional, once the improvement of the treatment may be related to the maintenance or elimination of the abuse episodes. The speech pathologist should, therefore, expose this complex problem and, specially, "give voice" to children silenced by the violence, understanding that behind the silence there might be a cry for help. 


\section{References}

ANDRADE, C. R. F. Prevalência das desordens idiopáticas da fala e da linguagem em crianças de um a onze anos de idade. R. Saúde Públ., v. 31, n. 5, out. 1997.

BRAZ, M.; CARDOSO, M. H. C. A. Em contato com a violência: os profissionais da saúde e seus pacientes vítimas de maus-tratos. R. Latino-Am. Enf., v. 8, n. 1, p. 91-97, 2000 .

COCHRAN, W. G. Técnicas de amostragem. Rio de Janeiro: Fundo de Cultura, 1965.

DESLANDES, S. Atenção a crianças e adolescentes vítimas de violência doméstica: análise de um serviço. Cad. Saúde Públ., v. 10, supl.1, p. 177-187, 1994.

DESLANDES, S. O atendimento às vítimas de violência na emergência: prevenção numa hora dessas? $\mathrm{Ci}$. Saúde Col., v. 4, n. 1, p. 81-94, 1999.

EIGSTI, I. M.; CICCHETTI, D. The impact of child maltreatment on expressive syntax at 60 months. Devlop. Sci., v. 7, n. 1, p. 88-102, 2004.

GOMES, R.; JUNQUEIRA, M. F. P. S.; SILVA, C. O.; JUNGER,W. L. A abordagem dos maus-tratos contra a criança e o adolescente em uma unidade publica de saúde. Ci. Saúde Col., São Paulo, v. 7, n. 2, p. 275-283, 2002.

GONÇALVES, H. S.; FERREIRA, A. L. A notificação da violência intrafamiliar contra crianças e adolescentes por profissionais de saúde. Cad. Saúde Públ., Rio de Janeiro, v. 18, n. 1, p. 315-319, jan.-fev. 2002.

HAMMOND, J.; NEBEL-GOULD, A.; BROOKS, J. The value of speech-language assessment in the diagnosis of child abuse. J. Trauma, v. 29, n. 9, p. 1258-1260, sep. 1989.

KVAM, M. H. Sexual abuse of deaf children: a retrospective analyses of the prevalence and characteristics f childhood sexual abuse among deaf adults in Norway. Child Abuse Negl., v. 28, n. 3, p. 241-251, mar. 2004.

LAW, J.; CONWAY, J. Effect of abuse and neglect on the development of children's speech and language. Dev. Med. Child Neurol., v. 34, n. 11, p. 943-948, nov. 1992.

LIMA, D. A.; GAMONAL, A. Síndrome da criança maltratada. HU R.: R. Méd. Of. Hosp. Univ. Fed. Juiz de Fora, v. 26, n. 2 e n. 3, p. 237-239, maio-dez. 2000.

MELLO, J. S. Notificação compulsória de maus-tratos contra criança e adolescentes do estado do Rio de Janeiro: descrições preliminares. 2002. xx f. Monografia (Especialização em Saúde Pública) - ENSP-FIOCRUZ.
MOREIRA, D. R.; FRIEDMAN, S. Fonoaudiologia: o sentido que se produz nas áreas médica, odontológica e fonoaudiológica. Pró-Fono R. Atual. Cient., Carapicuíba (SP), v. 14, n. 1, p. 129-136, jan.-abr. 2002.

NATIONAL CLEARING ON CHILD ABUSE AND NEGLECT INFORMATION: administration for children and families- US. Department of Health and Human Services. 2004. Child Maltreatment 2002. Disponível em: <http:// nccanch.acf.hhs.gov>. Acesso em: 12 de abril de 2004.

NOGUCHI, M. S.; ASSIS, S. G.; SANTOS, N. C. Entre quatro paredes: atendimento fonoaudiológico à criança e adolescentes vítimas de violência. Ci. Saúde Col., v. 9, n. 4, p. 963-973, out.-dez. 2004.

NOGUCHI, M. S.; ASSIS, S. G. Fonoaudiologia e violência intrafamiliar contra crianças: identificação de casos e prevenção. Pró-Fono R. Atual. Ci., v. 15, n. 2, p. $199-$ 206, 2003.

SECRETARIA ESTADUAL DE SAÚDE DO RIO DE JANEIRO. Dados Epidemiológicos: notificação de maustratos contra a criança e o adolescente. Disponível em: $<$ http://www.saude.rj.gov.br>. Acesso em: 12 de abril de 2004.

SILVA, A. P. B. V.; MASSI, G. A. Práticas Fonoaudiológicas: uma análise histórica. Pró-Fono R. Atual. Cient., Carapicuiba (SP), v. 11, n. 1, p. 150-152, 1999.

SILVA, K. H. A Notificação de maus tratos contra crianças e adolescentes pela secretaria municipal de saúde do Rio de Janeiro aos Conselhos Tutelares: em busca de uma parceria. 2001. xx f. Dissertação (Mestrado em xxx) IFF-FIOCRUZ.

SUlliVAN, P. M.; BROOKHOUSER, P. E.; SCANLAN, J. M.; KNUTSON, J. F.; SCHULTE, L. E. Patterns of phisycal and sexual abuse of communicatively handicapped children. Ann. Otol. Rhinol. Laryngol., v. 100, n. 3, p. 188-194, mar. 1991.

TFOUNI, L.V.; FERRIOLLI, B. H. V. M.; MORAES, J. A concepção de sujeito na clínica fonoaudiológica: a proposta de um novo paradigma. Pró-Fono R. Atual. Cient., Carapicuíba (SP), v. 14, n. 2, p. 275-282, maio-ago. 2002.

VIEIRA, A. R.; MODESTO, A.; ABREU, V. I. Avaliação dos casos de abuso infantil do Hospital Municipal Souza Aguiar (Rio de Janeiro) e sua relação com o cirurgiãodentista. Pediatr. Atual, v. 11, n. 1 e n. 2, p. 21-32, jan.fev. 1998 . 